\title{
THE INNOVATIVE WAREHOUSE ACTIVITIES OF GYERMELYI HOLDING PLC. PASTA FACTORY
}

\author{
Egressy Dóra, Lados Kitti, Csáki Dávid, Rácz Georgina \\ Szent István University, Faculty of Economics and Social Sciences, Institute of Business \\ Studies
}

\begin{abstract}
The aim of this study is to analyze the logistic processes of the innovative warehouse of Gyermelyi Holding Plc. and its effects on the company. If the logistic processes are built appropriately, then due to the decrease of expenses incurred, it improves the efficiency of the company's operations. For the research, we are mainly concentrating on the scientific investigation of the amount of shipped products, the rate of pick-ups and the formation of the workforce fluctuation. We survey the reason why this company wanted to make a unique investment happen, how this effected the market share and the company's revenue. The findings of the research are based on the interview that we had with the managers of the company. The results of the innovation have been worked out by using a variety of statistical methods. In conclusion, by comparing the before and after status of the warehouse enlargement, we can confidently state that this long-term investment is rewarding for the company. Using an innovative warehousing technique can lead to a significant improvement in the logistic processes, as well as support the implementation of future goals.
\end{abstract}

Keywords: automated high-bay warehouse, innovation, increasing efficiency, increasing productivity

\section{Introduction}

As consumer society grows, companies are in need of having a greater range of products, reduced lead times and constantly improving customer service. The high-level expectations of customers to ensure modern products, excellent quality, quick and prompt road transportation may present major challenges to the companies. All of these cause companies to use modern methods in their operational processes (Bailey, 2015). Installing innovative techniques in the processes of storing will result improved efficiency, better managed supplies, better planning and increased transparency. Installing techniques in warehouses, such as automated high-bay storage has many benefits: it guarantees full automation in orders patching, faster flows of goods, easier placing in storage and picking, cost-efficiency and shorter process time in reaching products (Schäfer, 2015).

\section{Company overview}

In the Hungarian market this unique innovation was exclusively realized by one pasta factory, the Gyermelyi Holding Plc. Since they became a Public Limited Company in 1971, due to their continuous investments and developments, they have integrated their activities. Beside manufacturing high quality raw materials, products are also produced with the most modern machines (Gyermelyi, 2013). It is important to note that most customers think of Gyermelyi as a pasta brand. But in addition, eggs and flour are also available in the consumer market under the name of Gyermelyi. According to an interview with the Assistant Director of Marketing, the goal is to strengthen the brand expansion of Gyermelyi, which includes the eggs and flour 
as well (Bokros, 2014).Since 2013 the warehousing processes of the company have been working properly, due to their 2 stage investment, achieved for more than a decade (Bederna \& Mohr, 2015).

\section{Background assessment based on the interview}

We had the chance to get to know the pasta factory's logistics activities through an interview, which we conducted with the Logistics and Warehouse managers. During the interview we asked them about the reasons for the innovation and the future targets set by the company.

\section{What were the problems that caused the need for innovation?}

We had to make a decision - said the Logistics manager - and change the system of storing because we could not handle the large amount of products stored in the warehouse, the systematization, the order-picking and the delivery of the products anymore. Before 2004, the warehouse was not modernized, but it could satisfy all the processes at that time. Since then, the storing needs have increased, and with the old system we were not able to manage these. The reason is that around 2004, an innovative technique was discovered. A pasta production line was created, and we could produce sufficiently, but the warehouse was at maximum capacity. When we outsourced the process of order-picking to one of the enterprise's subsidiaries, we delivered the pallets to them. Their workers were given the tasks of picking, transferring them in and loading the trucks. At the time, it proved operational because we only produced 80 items but on the other hand, it was a completely uneconomical solution. This led to the idea that next to the automatic high-bay, in the shipping area, we would setup roller tracks. The loading of the trucks with pallets and smaller amount of products are implemented here.

What are the advantages of the warehousing techniques of Gyermelyi Plc. compared to its competitors?

This is a unique kind of warehousing technique in Hungary. When the management of the pasta factory travelled to Switzerland to visit the automated storing practice operating there, it convinced them to use this technique, as it would mean a significant improvement in the logistic processes of the company. The primary aim was not realizing savings, but rather taking a great leap forward for the good of improvement. The company can only achieve this extended production by applying these warehousing methods.

\section{When did you start the enlargement of storage and when did you finish it?}

The enlargement of the warehouse was divided into 2 phases. The first one occurred in around 2004, but this expansion was not sufficient. Therefore other improvements were needed, which were completed 3 years ago. The place has already been built, the development utilized, and therefore the 2 systems have been working simultaneously since then.

\section{Was the external spread also a reason for innovating the warehouse?}

Around 2004, during the development, the external spread was not our intention. Gyermelyi Plc. started exporting only 4 years ago, which represents $10 \%$ of the total production. The management envisions the future mostly in this way of extension because increasing our $40 \%$ market share in Hungary, would put the activities of the company in danger and would increase 
our risk exposure. The $40 \%$ growth could only be achieved by selling at unrealistically low prices, which would not pay off in a long run.

\section{What further purposes has Gyermelyi made up so far?}

Currently, the production in the field of technology has been 95\% exploited, which is considered quite remarkable. For this year, we have created 2primary goals - said the Logistics manager. In 2015, according to our plans, we wish to reach 30 thousand tons of production volume and increase the production efficiency of our machines by $10 \%$. Most importantly, the leadership is focused on the central premise. This can be gained by establishing an entirely new agricultural base on a different premise, so as to gain ground for further expansion of the production facility (Bederna \& Mohr, 2015).

\section{The introduction of the present logistic processes of Gyermelyi Plc.}

The 1. figure shows the flow of goods from the manipulation area to the shipping area, after which the goods are delivered to their destinations. The process is presented in the following chapters in detail.

\section{The role of the manipulation area}

By studying the on-going storing processes in this section, we present the flow of products going from manufacturing to delivery. In the manipulation area, the production line is connected to an automatic conveyor, where a carrier takes the items to the automated packaging machine and the carton machine. After placing the items onto pallets (EP-01), the unit loads arrive from the receiving point to the central wrapping machine, which prepares the products for inspection. Following the wrapping, the pallets go through a data recording, which is operated by a scanner run by a warehouse control software. The EUR pallets are marked with identification tags that contain important data, such as the serial number, unique code and the expiry date of the products. The system knows exactly which conveyor the pallets are coming from and then reads their tags. The pallets move along the conveyor belt in the direction of the weighing point (IP-01), where upcoming actions are decided. If they meet all the requirements (weight, height, width), they could be placed in the warehouse. However, if a pallet does not meet the criteria, it is sent to the so called wasting point (AS-01), where the day shifters proceed according to the error messages shown on the display. In case of an error because of weight, the pallets are set aside, after which they control the conformance of the identification tags. If the problem is not resolved, the manager of the packaging area has to be informed, as he or she is in charge of finding out and solving the problem (Bederna, 2014). In order to speed up processes, they make the pallets fully ready on the automated system of the manipulation area, according to the delivery order and the axle load of the trucks. Because of this method, the pallets are transferred to the warehouse in approximately thirty seconds. In the old system the material handling was only done by forklifts, which would not be able to handle this fast moving system. Today each load is either moved by forklifts or the automatic system. Due to the innovation, the products produced on one day, can be sold the very next day (Bederna, 2015/c)(see 1. figure). 


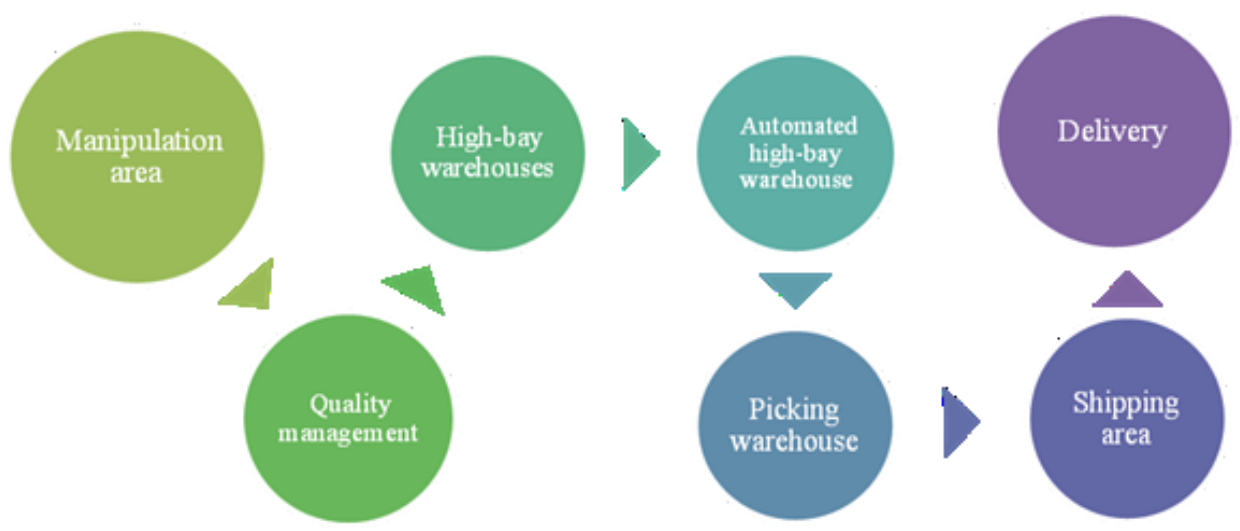

\begin{abstract}
1. figure: The path of goods from the manipulation area to the shipping area Source: own construction based on company documentation of Gyermelyi Plc.
\end{abstract}

\title{
Packaging warehouse
}

In the packaging warehouse, storage is solved by the configuration of serial access storage and drive-in pallet racks. In this type of storage method, the packaging materials are placed on the right and left side of the aisles. This way, 2 rows of pallet racks can be created next to each other, which creates the advantage of the packaging materials being easily reached (Prezenszki, 2002). The materials used by the pasta factory, the mill and the egg packaging are also stored here. From here, the materials are carried to the storage hall by forklifts, where they are placed on separate racks according to the upcoming production needs (Bederna, 2015/c).

\section{Quality management}

In order to keep their quality products, quality management is an essential step for pasta factories. There is always a quality check of pasta and mill products before they are sent to the warehouse. The function of the laboratory is to filter out products during auditing that are below the quality regulations. Only Normal state products can be placed in the warehouse. In case of not meeting the requirements, they place them in the Quaran state. These items cannot be taken out of the warehouse for sale purposes because they have to be tested again (Bederna, 2014)(see 1. figure).

\section{Formation of high-bay warehouses}

Beside the pasta products, mill products are also kept in these warehouses. Due to the continuously growing product range of Gyermelyi Plc., establishing additional drive-in based storing capacity was created recently. After the first phase of the enlargement of the warehouse, which occurred in 2004, it can receive around 6,400 pallets. Later, in 2011-2012 the further enlargements resulted in another 3,300 pallets being able to be received. That resulted in 2 separate warehouses being built next to each other, as both are connected with the conveyor belt of the pasta factory. In one of the warehouses, the standard $1260 \mathrm{~mm}$ high pallets are stored. In the other storage unit 2 types of locations can be found, which are 1600 and $1800 \mathrm{~mm}$ high (Bederna, 2015/c) (see 1. figure).

\section{Automated high-bay warehouse}

Due to the system implemented by the German SSI Schäfer in 2004, Gyermelyi Logistics Ltd. is able to support the company's logistics processes by this unique method. The company 
Gyermelyi Logistics Ltd. as subsidiary, was established in the context of tender possibilities in 2010. This company is an integral part of the Gyermelyi Holding that enables a more effective coordination of processes (Bederna, 2015/b).

The automated high-bay warehouse is 47 meters long, 22 meters wide and 26 meters high. Pallets are placed in the warehouse in6double-deep rows. One row is 37 positions long and 14 positions high, thus the maximal capacity of the warehouse is 6216 EUR pallets. The first stage of the warehouse system is operating with 3 automated machines, which is able to store 500 pallets in 16 hours and send out 550 pallets in 24 hours. In the complete system there are more than 200 types of pasta products and 15 types of mill products, stored in 5 rows and placed in 2 deep channels. The moving of placements and dispatching of the products is done by an automated carrying machine (RBG). The warehouse management system handles the stock, taking into account the principle of First In First Out (FIFO) and contributes to delivering products before their expiration date (Bederna, 2004).
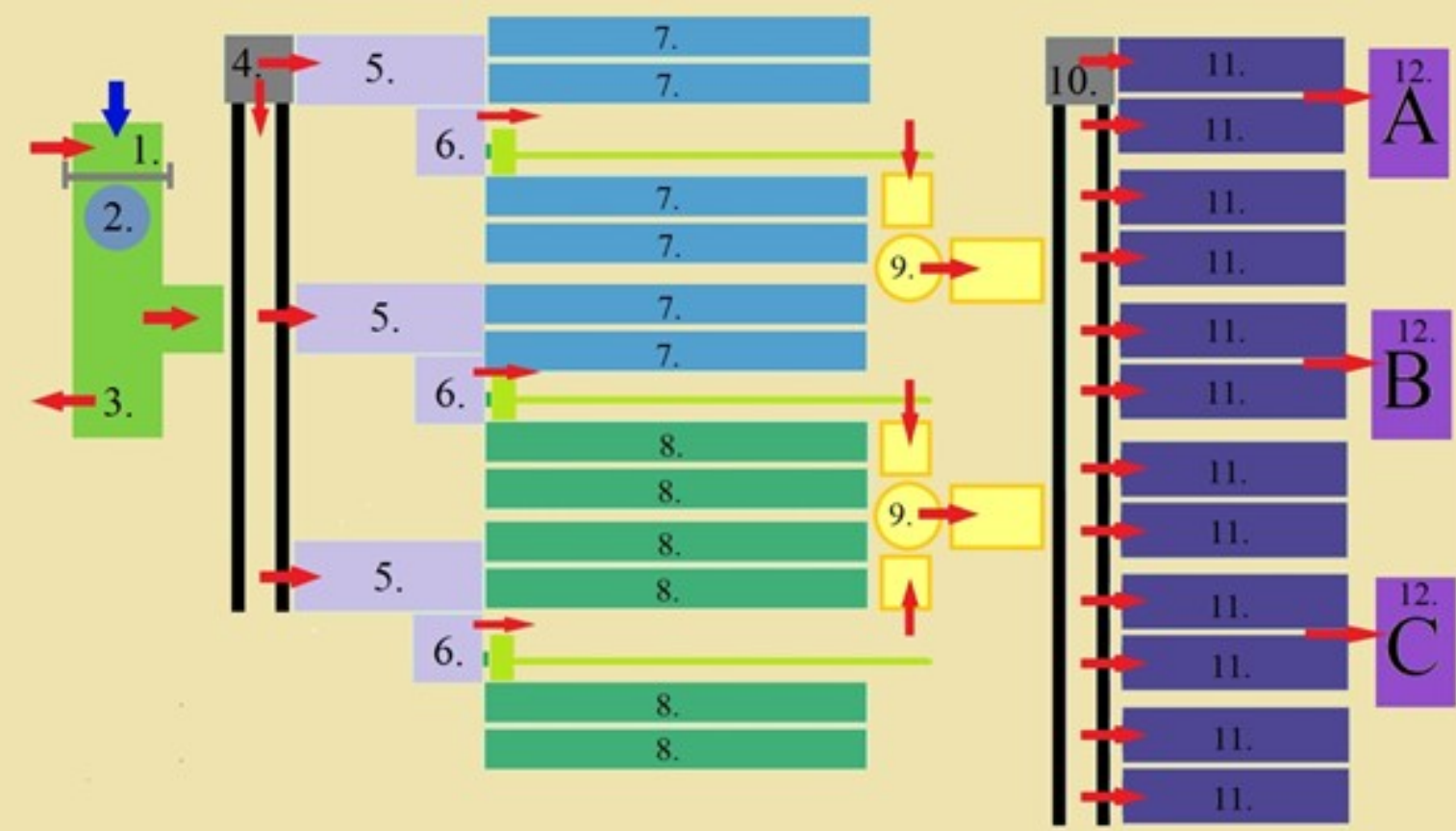

1. transferring point ( EP-01)

2. identification and control point ( IP-01)

3. point of waste ( AS-01)

4. motorized transfer on the side of receiving

5. chain conveyors

6. automatic machines ( RBG1, RBG2, RBG3)
7. automated high-bay warehouse

8. high-bay warehouse

9. motorized rotating turntables

10. motorized transfer on the side of shipping

11. roller tracks in the shipping area

12. $\mathrm{ABC}$ loading docks

\section{2. figure: The flow chart of the automated high-bay warehouse}

Source: own construction based on company documentation of Gyermelyi Plc.

The processes in the warehouse areas follows. In the section of the pasta factory the pallets are placed onto the EP-01 transferring point. The EUR pallet then passes to the IP-01 identification and control point. Before storing a necessary check is needed. In case of any problems, pallets are moved to the AS-01 point of waste products. After that, the places for storaging are selected, which is naturally done by a fully automatic way. The WAMAS warehouse management system handles the operational control of the logistics and other flows of goods. The management program meets all the requirements of any listing or logging needs, thus all processes and the storing of pallets can be retrieved quickly and efficiently. The management system sends the 
command of picking to the Enterprise Resource Planning software, which contains the type of products and quantity needed. During the shipping process, the products that have spent the most time in the warehouse are picked first, thus, in addition to the careful production plan, there are no products close to the expiration date left in the warehouse (Bederna, 2004)(see 2. figure).

\section{Picking warehouse}

In this warehouse, the products are stored on the ground level of racks, the higher level is used for the replacement of products. As in the high-bay warehouse, the flow of goods is managed by the WAMAS warehouse management system. The only difference is that this warehouse does not have automated equipment, so the flow of goods is done by forklifts. As was mentioned before, all the pallets are marked with a unique identification tag before they are placed in the high-bay warehouse. When they arrive in the picking warehouse, these tags are read and processed by mobile data collectors. The same instructions appear on the screen of the mobile data collectors as the automated forklift trailers receive in the high-bay warehouse. Each location is marked by an identifier. The reason for this is because when the pallets are transferred from the high-bay warehouse to the picking area, they read the identification tags that indicate where to locate them (Bederna, 2015/c).

Each pallet can be queried(location, the number of item, quantity, serial number, the time of placement in the warehouse, etc.).During picking, the pickers remove the right amount of products from the given location and then book by reading the barcode. The picking order always starts at the beginning of the row. The picker continues picking the next row and then returns to the other side. They collect the item within each of the orders according to this method. The placing of items in the picking warehouse was not created by the strategy of the products' turnover ratio but primarily by taking into account the stacking aspects of the products (Bederna, 2014). They receive orders for next-day delivery until 9 AM, at EDI (Electronic data interchange), by e-mail, phone or fax. After 10 AM they start the automatic pallet shipping operations. The loading instructions received from the freight forwarders are scheduled by taking into account the arrival time of the trucks. In conclusion, the most important part is that the order of picking has to be based on the loadability and stability of products. The largest products are put at the bottom of the pallet (Bederna, 2015/c)(see 1. figure).

\section{Shipping area}

The Enterprise Resource Planning system JD Edwards provides basic information to the independently working WAMAS warehouse management system. The system coordinates the flow of goods in the warehouse, receives the needs and answers to the ERP system. The unit loads arriving to the shipping area are marked with identification tags, which are queried from this system. These tags contain such information as, the order number of the product, the location on the roller tracks, customer number, customer name and the name of the ordered product (Bederna, 2015/c)(see 1. figure).

\section{Delivery}

The innovations have had a huge effect on warehousing but increased the efficiency of delivery as well. Before the innovation, the company satisfied the needs of customers with 624 -ton trucks and 3 vans. At that time bulk delivery was typical. The production fluctuated between 14,000 and 18,000 tons. Since the picking and loading docks have been built, smaller packs are 
also sold, as well as the pallets. In addition to the retail customers, the number of bakeries and smaller shops also increased. They outsourced the deliveries to local entrepreneurs, who nowadays are picking up items many more times than they previously had. The biggest reason of outsourcing this action is that the production grew from 14,000 tons to 27,000 tons. The daily number of freight shipments increased from 10 to 35-40 times per day (Bederna \& Mohr, 2015)(see 1. figure).

\section{Results}

Improved efficiency in the area of logistics

Since 2005, thanks to the modified organizational structure of logistics, the company has managed to rationalize each division. On the basis of the obtained data, we measured the impact of the implemented logistics improvements on the following divisions at Gyermelyi Plc. pasta factory.

\section{Procurement}

Concerning the inbound logistics of Gyermelyi Plc. it is a key requirement for the raw materials and other products, such as packaging materials to arrive in the company at the right time, in the right quantity, as well as in the suitable quality.

1. table: The formation of staff in the area of purchasing in $\mathbf{2 0 0 5}$ and 2015
(members/year)

Source: own construction based on company documentation of Gyermelyi Plc.

Today, the whole procurement is made through the central warehouse. In relation to this - the trade corresponding to 120 million HUF -, the total purchase can be handled by 7 less staff members, compared to 2005 (Bederna, 2015/a) (see 1. table).

\section{Storage}

Within the framework of the modernized in-house logistics system, after the pasta manufacturing and packaging, the finished products are transported to the warehouses. In Gyermely, at the central premise of the company, the finished goods are stored altogether on 13,200 pallet locations. In addition, 2,100 pallet locations are available for storing wrapping materials. In a separated warehouse, 1.5 million pieces of eggs are stored. (Bederna, 2015/b). As a result of the development, it was necessary to restructure the labour force, which is shown in the table below. 
2. table: Number of employees in different activities of storage in 2005 and 2015 (employees/year)

\begin{tabular}{lcc}
\hline Sphere of activity & $\begin{array}{c}\text { Number of } \\
\text { Employees in 2005 } \\
\text { (employees/year) }\end{array}$ & $\begin{array}{c}\text { Number of } \\
\text { Employees in } \\
\mathbf{2 0 1 5}\end{array}$ \\
\hline $\begin{array}{l}\text { Warehouse manager } \\
\text { Staff of the warehouse of finished } \\
\text { products }\end{array}$ & 1 & 1 \\
$\begin{array}{l}\text { Staff of the high-bay warehouse } \\
\text { Picking staff }\end{array}$ & 2 & 1 \\
$\begin{array}{l}\text { Staff of the flour warehouse } \\
\text { Staff of the warehouse of packaging } \\
\text { materials }\end{array}$ & 4 & 2 \\
$\begin{array}{l}\text { Staff of the department of the pallet } \\
\text { warehouse }\end{array}$ & 1 & 3 \\
Administrative assistant & 2 & 3 \\
Cleaning staff & 2 & 2 \\
Total & 1 & 0 \\
\hline
\end{tabular}

Source: own construction based on Gyermelyi documentation of Gyermelyi Plc.

What we can see from the 2. table is that the picking process requires one less employee, while the packaging process requires one extra employee in 2015. Additionally, there was a slight increase in the number of staff in the flour warehouse compared to the year 2005. Moreover, thanks to the automation, the staff members are not employed full-time. Its number decreased by 2 employees. As the cleaning activity is outsourced to an external company, Gyermelyi Plc. can save costs. In summary, based on our experiences it can be concluded that growing production and expanding warehouse capacities can lead to workforce transfer and the number of staff decreased from 15 to 13 in the warehouse.

\section{Removal process}

In addition to the automated high-bay warehouse of the shipping side, the company has developed roller tracks. From this place the trucks are loaded with outgoing goods. While 6 employees loaded the trucks by hand in 2015, today these tasks are done by fully automated machines (Bederna, 2015/c).

\section{Delivery}

Due to the current production in Gyermely, the company can take advantage of road transport exclusively. This is the best and the most cost-effective solution for the company. Within the developed outbound logistics system, the delivery was outsourced to external companies. As a result, there was no need to employ drivers. The outsourced fleet consists of 4 permanent subcontractors where nearly all of the 14 drivers of Gyermelyi Plc. were given a job. The tasks connected to transportation are carried out by 2 people within the company. According to the data taken from the warehouse manager's summary, from 2013 to 2014 in addition to the delivered quantity, the number of mileage also increased. The delivered quantity rose by $10,000,000$ kilograms in 2014 compared to the previous year. In terms of mileage, the vehicles are running 400,000 kilometers more per year than before. In terms of milk run tours (milk run tour is a special term for delivery of smaller unit loads to bakeries, restaurants etc.), the carriage fees increased by $13.3 \%$ and the delivered quantity rose by $5.3 \%$. The number of destinations increased by $67.2 \%$ which is an outstanding data (Bederna, 2015/b). 


\section{Electronic Public Road Trade Control System}

In order to track the actual route of the goods, the Electronic Public Road Trade Control Systemwas initiated by Gyermelyi Logistics Ltd., based on the newly introduced Government Regulation. The regulation ensures the payment of taxes incurred during the course of supplies and sales, as well as reporting compulsory good sales to the Valuation Office Agency. That causes a significant administrative burden, the increase in the staff by one person, as well as making the processes of the parcels delivery becoming complicated (Bederna, 2015/b).

\section{Summary}

Owing to the development implemented in the company in 2004, there were major changes made in the logistics department. As a result, $44 \%$ fewer employees could fulfil the growing orders.

This diagram represents the change in the number of full-time employees between 2005-2011.

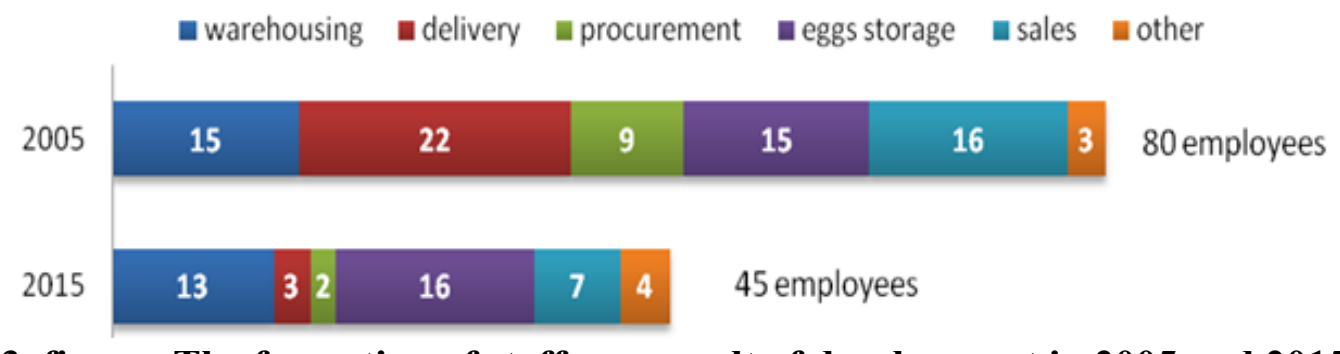

\section{3. figure: The formation of staff as a result of development in 2005 and 2015 (employees/year)}

Source: own construction based on company documentation of Gyermelyi Plc.

The changes occured due to several factors. As can be seen in the3. figure, the greatest decrease was caused by the outsourcing of transportation. It is crucial to mention that Gyermelyi Logistics Ltd. has outsourced its shipping operations. In this case, the corporation must pay only outsourcing fee, thus it may save money on operations, vehicle maintenance, and employees. The centralization of procurement reduced the necessary headcount by 3 people while the transform of sales did so by 9 . Naturally in every sphere of activity, in every field they work with different wages. Therefore, in addition to the stock changes, the impact of development and restructions on costs are worth investigating. While before 2004, a worker was able to handle approximately 2,100 tons of products, in 2015 the amount was 5,000 tons of products per worker. The wages rose by $10 \%$ in order to meet the growing demands in payment. However, the wage cost per ton fell by 50\% (Bederna \& Mohr, 2015).In summary, the restructions and developments resulted in a formation of a quite efficient company structure, which efficiency extends to nearly every part of the company's effectiveness.

\section{Fluctuation of Inventory}

The efficient use of stock depends on many factors, such as the production equipment capacity, lead-time, moreover its current financial opportunities and the way of customer services. It is recommended to companies to keep as much stocks, which size is able to ensure smooth flow of materials on the lowest stock levels. This can be measured by the turnover ratio indicator. This indicator represents the efficiency of goods turnover (Econom, 2010). 
The data from 2004 to 2009 show that the inventory turned over with an averageof 4 times a year. Then, there was a substantial growth, where turnover rate reached a peak at more than 5 times in 2011. Afterwards, it fell again to 4 times a year (see red line of 4 . figure). The main reason of this is that the company launched its own commercial brands on domestic markets and at the same time, began to expand in foreign markets. In summary, the company took the necessary steps well before the development in order to prepare for achieving the future goals.

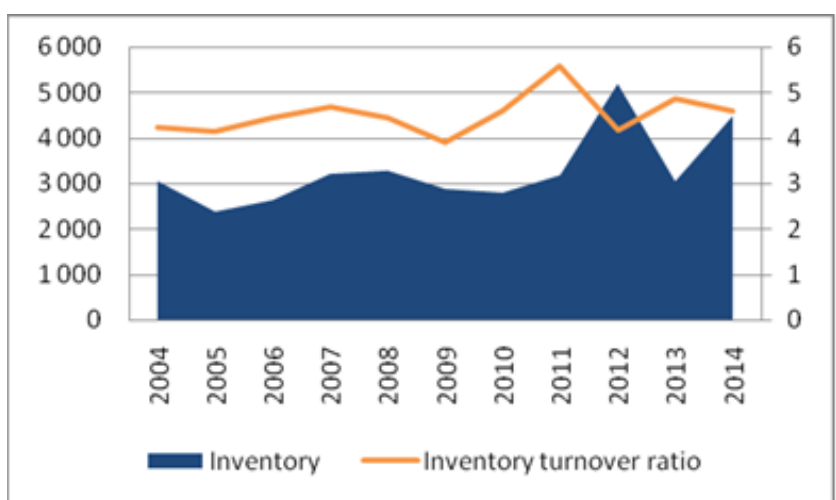

\section{4. figure: The relationship between inventory (in million HUF) and inventory turnover ratio (in \%) between 2004 and 2014}

Source: own construction based on www.e-beszamolo.kim.gov.hu

\section{Financing of investment}

The 5. figure shows the amount of bank loans over the last 10 years. The company needed around 1-1 billion HUF in loans for investments in the last decade. In some areas the implemented modernization required the development of the related fields in the company. The investments were mainly covered by the company's own financial resources and bank loans. In addition, a small proportion of state support was also provided. In 2005, the Gyermelyi Plc. borrowed 1 billion HUF to execute the first stage of the warehouse development. The main reason for this is that consumers recognized the company's high-quality products and the demand for different types of pasta increased. Thus the production volume rose steadily over the past years. In the next years the Hungarian government provided financial support for the construction of the second mill, for a regional warehouse and a poultry farm. As we can see that from 2012, there was a sharp increase in the amount of loans. It reached a peak ataround1.5 billion HUF. Gyermelyi Plc. successfully implemented the second-stage of the warehouse expansion and bought harvesters. This led to more effective production, storage and transport processes.

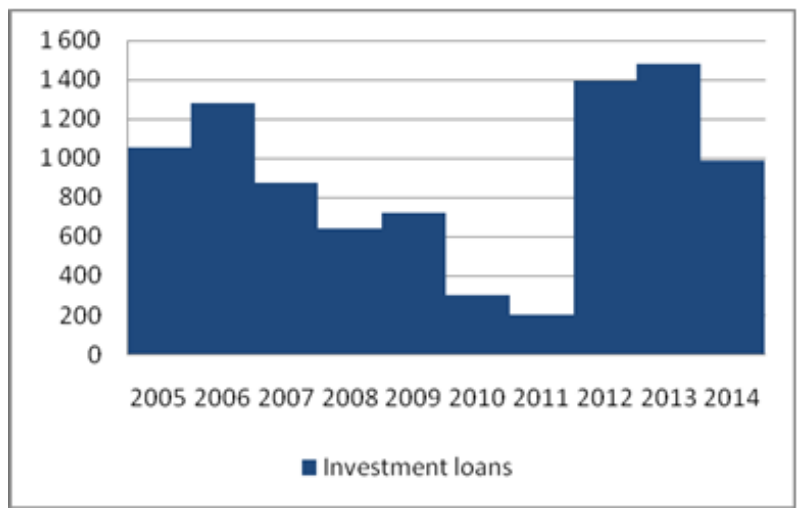

5. figure: The formation of investment loans between 2005 and 2014 (million HUF/year) Source: own construction based on www.e-beszamolo.kim.gov.hu 


\section{The developments in the year 2012}

The company accomplished the second major warehouse development in 2012. We analyzed the changes in some important logistics indexes based on data between 2011 and 2014. The data in the 3 . table show the average weekly rates.

As it may be seen from the 3. table, the developments resulted considerable improvement in efficiency. The average route utilization fell minimally by $0.9 \%$. This includes that the departured consignment per performed order quantity grew by $12.36 \%$ compared to the year 2011, which indicates that up-to-date technology allows more efficient transport.

Moreover, there was a remarkable, 53\% rise in the number of supplied logistics destinations per week. As a result, it was possible to serve - on average - 560 pieces logistics unit from the main store per week in 2014.

The development of the automatic picking system has resulted in a $21 \%$ growth in unit load efficiency. Due to the development it is possible to collect and match $146 \mathrm{~kg}$ more products according to the orders in one hour.

\section{3. table: Primary results in 2011 and 2014}

\begin{tabular}{|c|c|c|c|c|}
\hline Fields of investigation & Calculation & 2011 & 2014 & Fluctuation \\
\hline $\begin{array}{l}\text { AVERAGE ROUTE } \\
\text { UTILIZATION (\%) }\end{array}$ & $\begin{array}{l}\text { Delivered amount of goods } \\
\text { (tons) / Maximum capacity of } \\
\text { transport equipment (tons)*100 }\end{array}$ & $69.40 \%$ & $68.50 \%$ & $-0.90 \%$ \\
\hline $\begin{array}{l}\text { NUMBER OF LOGISTIC } \\
\text { DESTINATIONS }\end{array}$ & $\begin{array}{l}\text { Supply of logistic destinations in } \\
\text { a period (piece) }\end{array}$ & $364 \mathrm{pcs}$ & $560 \mathrm{pcs}$ & 195 pieces \\
\hline $\begin{array}{l}\text { PERFORMED ORDER } \\
\text { QUANTITY PER FREIGHT } \\
\text { TASK }\end{array}$ & $\begin{array}{l}\text { Performed order quantity (piece) } \\
\text { / number of departured freights } \\
\text { (piece) }\end{array}$ & $4.45 \mathrm{pcs}$ & 5 pcs & 0,55 pieces \\
\hline $\begin{array}{l}\text { PRODUCTIVITY OF } \\
\text { PICKING PROCESS }\end{array}$ & $\begin{array}{l}\text { Picked quantity }(\mathrm{kg}) / \text { completed } \\
\text { working hours in warehouse } \\
\text { (hours) }\end{array}$ & 692 & 838 & $146 \mathrm{~kg} / \mathrm{h}$ \\
\hline $\begin{array}{l}\text { PRODUCTIVITY OF } \\
\text { STORAGE PROCESS }\end{array}$ & $\begin{array}{l}\text { Delivered amount of pasta, eggs, } \\
\text { flour }(\mathrm{kg}) \text { / completed working } \\
\text { hours in warehouse (hours) }\end{array}$ & 4671 & 5472 & $801 \mathrm{~kg} / \mathrm{h}$ \\
\hline $\begin{array}{l}\text { TURNOVER RATIO OF } \\
\text { FINISHED PRODUCTS } \\
\text { (PASTA) }\end{array}$ & $\begin{array}{l}\text { Weekly level of closing stock } \\
\text { (day) / Total (Gyermely and } \\
\text { warehouses) daily average sales } \\
\text { in last quarter (days) }\end{array}$ & 54 & 51 & -3 days \\
\hline
\end{tabular}

Source: company documentation of Gyermelyi Plc.

The developments had a positive effect also on the productivity of the storage process. The mentioned indicator rose by $17 \%$, which plays an important role in meeting the increased demand on time. Currently, the highest removal rate could reach or even exceed 120 pallets per hour, while using the old storage and material handling methods only 30 pallets could be removed and loaded onto trucks. 


\section{The exporting activities of Gyermelyi Plc.}

Export has been given a high priority in the company's strategy, as 2 items, domestic sales and export affect its net revenue significantly. In recent years, the volume of export has grown rapidly but at the same time, the net revenue also increased. Currently, the total sales represent $10 \%$ of the foreign market (see 6 . figure).

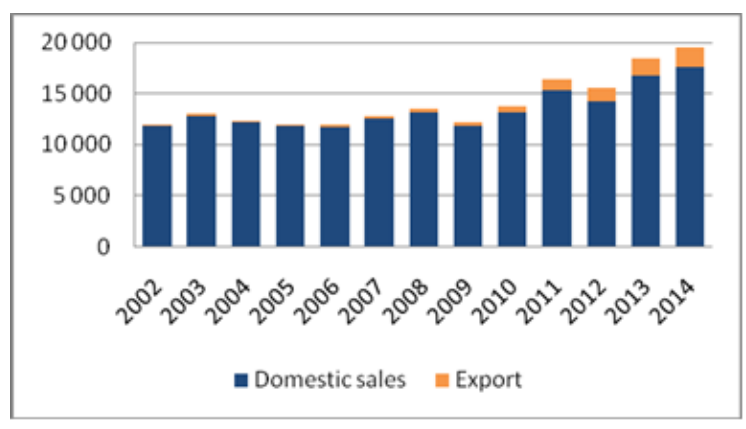

6. figure: Increased proportion of export within total sales between 2002 and 2014 (million HUF/year)

Source: own construction based on www.e-beszamolo.kim.gov.hu

The 7. and 8. figures represent the dynamics of domestic sales and export. We can observe a dynamic improvement beyond the rate of changes. While the domestic sales rose only by $5 \%$, the export increased by $32 \%$.

As a result of the dynamic growth, the company increased 3 times its net revenue coming from export during 3 years.

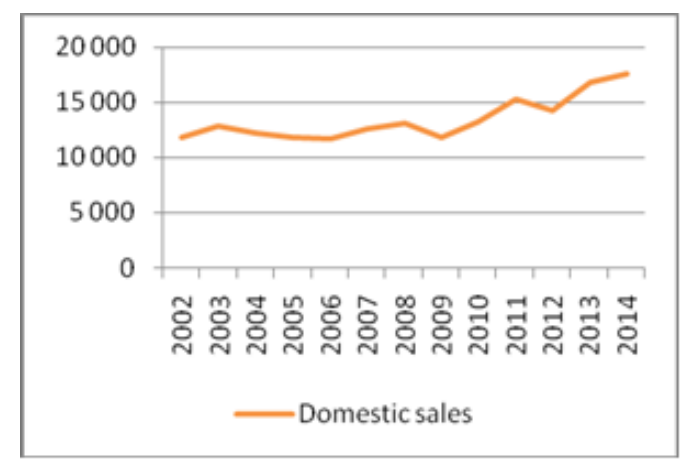

1. figure: The formation of domestic sales between 2002 and 2014 (million HUF/year) Source: own construction based on www.e-beszamolo.kim.gov.hu

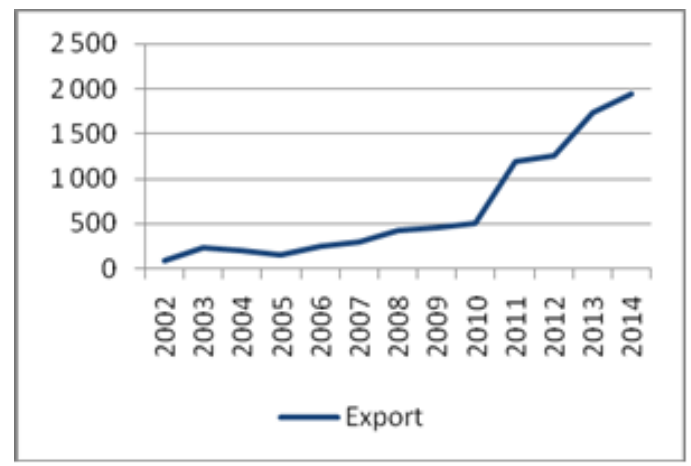

8. figure: The formation of export between 2002 and 2014 (million HUF/year)

Source: own construction based on www.e-beszamolo.kim.gov.hu 


\section{Conclusions}

The analyses carried out in this research, represent that what changes could be observed after the 2-phase expansion in the key investigated areas. The number of full-time employees changed from 80 employees to 45 employees. Thanks to the development, approximately $44 \%$ less staff could fulfil the growing orders (Bederna \& Mohr, 2015).

In addition, the picking ratio improved as well, thus the picking staff is able to collect and match $146 \mathrm{~kg}$ more products in one hour. This means that the unit-load training efficiency increased by $21 \%$ in 3 years (Bederna, 2012).

As a result, the storage activities became more productive compared to the state before the company could implement the development. The previous storage- and material handling activities were able to ship 30 pallets from the warehouse and load the trucks. In contrast, currently the highest shipping rate reaches the volume of 120 pallets per hour (Bederna, 2012). Since the transport activity is outsourced, freight has become more efficient. This finding is supported by the fact that compared to 2011, the average number of completed orders per freight increased by $12.36 \%$ in 2014 . Moreover, the served number of destination increased weekly by $53 \%$ as well. In this way, from the central warehouse of the Gyermelyi Plc. pasta factory, it is possible to serve 560 pieces logistics unit per week (Bederna, 2012).

\section{The vision of the company}

Beside the main areas of investigation, we assessed the effects of innovations on other factors. It was declared in the company's vision. Gyermelyi Plc. considers the expansion of export realization as a main target. In our homeland its market share rose from $33 \%$ to $34 \%$ in a time period of 8 years, although from 2012 to 2015 it went up to $40 \%$. In addition to this, net revenue rose from 11,949,536 thousand HUF to 19,502,465 thousand HUF (Gyermelyi, 2015).

This growth appeared by reason of - along with the prosperous, yet existing products - Vita pasta (made of durum wheat and no eggs) and DiVita, a unique, world patent product (Bokros, 2014). 10 years ago, the production capacity was reached, which forced the company to automate and enlarge their warehouse. Besides, the logistics software brought in made the operation more cost efficient and the storage expansion ensure more ergonomic working conditions for the employees as well (Bederna \& Mohr, 2015).

As for their plans, export realization will be carried out in more and more countries which mainly can be served from the master depot in Gyermely, partly served from the regional warehouses, as well as from the foreign subsidiaries of Gyermely Plc. According to their future goals, the present productions $10 \%$ export rate will be increasing continuously from year to year. The utilization of storage capacity has grown constantly beside the market share. It resulted in an always growing range of products, the appearance of foreign sales and the national tenders won (Bederna \& Mohr, 2015).

In terms of foreign markets, contracts were already signed with Slovakia, Romania and Ukraine. In their 5-year-plan Slovenia, Austria and Croatia are also listed. Further enlargements - such as newer pasta factory establishment - depend on their export activities and the success of contracting with foreign countries (Bokros, 2014). 
Overall, the management of Gyermelyi Plc. is far-seeing, accordingly they chose a strategy that can later be turned into the use of their operation.

\section{References:}

1. Prezenszki, J. (2002) Logistics II. (in English) DIG DAUBER Engineering office in Budapest

2. Resources on the Internet:

3. Bailey, M. (2015) The challanges of growing consumer demands. Source: ISSUU Logistics News Warehouse Annual 2015.: issuu.com/logisticsnews/docs/wha_2015_sample/1 Date of loading: 23 March 2015

4. Corporate history (in English). Source: Gyermelyi web site: www.gyermelyi.hu/index.php/cegtoertenet, Date of loading: 15 March 2015

5. Econom (09 January 2010). Inventory turnover ratio (in English) Source: Econom.hu website: http://www.econom.hu/keszletek-forgasi-sebessege/; Date of loading: 01 May 2015

6. Annual net revenue of Gyermelyi Plc. (2015)Ministry of Justice (in English). Source: Company Information and Electronic Company Registration Service: http:/ebeszamolo.kim.gov.hu/, Date of loading: 08 May 2015

7. SSI Schäfer (2015) Automatic picking (in English). Source: SSI Schäfer website: http://www.ssi-schaefer.hu/logisztikai-rendszerek/automatikus-komissiozas.html, Date of loading: 12 March 2015

8. Trademagazin (04 June 2013) SSI Schäfer innovative expansion of the warehouse at Gyermelyi Logistics Ltd. (in English). Source: Trade Magazine web site: www.trademagazin.hu/hirek-es-cikkek/ceg-es-szemelyi-hirek/az-ssi-schaferinnovativ-raktarbovitese-a-gyermelyi-logisztika-kft-nel.html, Date of loading: 06 March 2015

\section{Company documentations:}

9. Bederna, Z. (2004) company documentation of Gyermelyi Plc. pasta factory (name: Automated warehouse) (in English). Gyermelyi Plc. pasta factory in Gyermely

10. Bederna, Z. (2012) company documentation of Gyermelyi Plc. pasta factory (name: different types of analysis by data of KPI) (in English). Gyermelyi Plc. pasta factory in Gyermely

11. Bederna, Z. (2014) company documentation of Gyermelyi Plc. pasta factory (name: Logistics 6 v) (in English). Gyermelyi Plc. pasta factory in Gyermely

12. Bederna, Z. (2015/a) company documentation of Gyermelyi Plc. pasta factory (name: Logistics organization structure in 2005 and 2015) (in English). Gyermelyi Plc. pasta factory in Gyermely

13. Bederna, Z. (2015/b) Logistic report in 2015 (in English). Gyermelyi Plc. pasta factory in Gyermely

\section{Interview:}

14. Bederna, Z. (31 March 2015/c) Storage processes at Gyermelyi Plc. pasta factory (in English). Interviewers: Dóra Egressy and Kitti Lados

15. Bokros, G. (10 November 2014) Marketing and Logistic activities of Gyermelyi Plc. pasta factory (in English). Interviewers: Dóra Egressy and Kitti Lados

16. Mohr, R. and Bederna, Z. (19 March 2015) Warehouse innovation activity of Gyermelyi Plc. pasta factory (in English). Interviewers: Dóra Egressy and Kitti Lados 